\title{
ANALISIS PEMBUATAN SIMULASI 3D VIRTUAL REALITY SEBAGAI MEDIA TERAPI ACROPHOBIA
}

\author{
Astri Tania Tsani (1167050035),Mugni Purnamasari R (1167050094), Sri Desi Mulyani (1167050155) \\ Universitas Islam Negeri Sunan Gunung Djati Bandung \\ 1167050035@student.uinsgd.ac.id,1167050094@student.uinsgd.ac.id,1167050155@student.uinsgd.ac.id
}

\begin{abstract}
ABSTRAK
Acrophobia merupakan salah satu jenis phobia yang paling umum. Acrophobia adalah rasa takut yang tidak masuk akal yang membuat individu merasakan kegelisahan, ketegangan, dan rasa tidak nyaman ketika berada pada ketinggian. Hal itu membuat para penderita acrophobia tidak dapat menjelajah tempat yang tinggi. Untuk menyembuhkan phobia tersebut dibutuhkan terapi ke psikiater. Dalam teknik terapi, ada yang dinamakan flooding, yaitu sebuah teknik behavioral yang menghadirkan secara langsung stimulus atau sumber ketakutan yang menyebabkan seseorang mengalami ketakutan sampai penderita tidak merasa cemas dan akan belajar menghadapi ketakutannya sendiri. Teknik flooding ini sangat berbahaya bagi penderita acrophobia. Teknologi Virtual Reality telah digunakan untuk menangani penderita acrophobia, tetapi teknologi yang ada masih mahal. Oleh karena itu diperlukan sebuah teknologi yang murah agar para penderita acrophobia dapat melakukan terapi dengan aman. Dengan menggunakan Multimedia Development Life Cycle sebagai metode pengembangannya, Unity, dan aplikasi berbasis Android dapat mengatasi masalah tersebut.
\end{abstract}

Kata kunci-Acrophobia; Virtual Reality; MDLC; Unity

\section{PENDAHULUAN}

Phobia merupakan rasa takut yang membuat seseorang tidak nyaman. Penderita tidak tahu mengapa ia takut dan tidak dapat menghindari rasa takut itu. Dan kadang-kadang rasa takut itu menjadi bahan tertawaan orang sehingga ia semakin merasa cemas. Setiap orang memiliki ketakutan atau respons yang tidak menyenangkan terhadap objek-objek, situasi atau makhluk hidup. Beberapa respons ketidaknyamanan atau ketidaksukaan bersifat umum merupakan hal yang tidak terlalu perlu untuk diperhatikan. Akan tetapi, jika respons seseorang berlebihan terhadap sesuatu hal dan terlalu jauh diluar proporsi bahaya atau sikap yang mengancam simulus, orang tersebut dapat dikatakan memiliki phobia. Phobia spesifik yang paling banyak diderita salah satunya adalah acrophobia, atau phobia ketinggian. [1]

Virtual Reality adalah suatu teknologi yang membuat pengguna dapat berinteraksi dengan suatu lingkungan yang disimulasikan oleh komputer baik itu berdasarkan objek nyata maupun imajinasi yang bertujuan untuk mencapai rasa yang kuat atau nyata hadir di lingkungan virtual.[2] Pengguna teknologi Virtual Reality menggunakan alat seperti kacamata untuk mlihat adegan stereoscope tiga dimensi. Pengguna tersebut dapat melihat lingkungan sekitar dengan menggerakan kepalanya dan berjalan-jalan menggunakan kontrol tangan atau sensor gerak. Untuk mencegah kelelahan mata, objek yang akan dilihat oleh pengguna dengan matanya dalam jangka waktu tertentu (contohnya menu, objek yang menonjol pada lingkungan) harus menghasilkan antara sekitar 0.75 sampai 3.5 meter.[3]

Para peneliti telah melakukan penelitian terhadap efek samping Virtual Reality terhadap para pederita phobia. Total 83\% pasien yang menggunakan Virtual Reality memperlihatkan secara klinis peningkatan yang signifikan dibandingkan dengan pasien yang tidak menggunakan Virtual Reality , membuktikan bahwa Virtual Reality dapat secara efektif mengatasi phobia. Penekanan pada dunia Virtual terhadap penderita harus serelaks mungkin untuk meredakan kecemasan yang ada. Aplikasi yang ada digunakan sebagai alat relaksasi penderita ketika berada dirumah. Aplikasi ini memberikan kelebihan-kelebihan yang ada, dimana aplikasi ini dibuat sebagai alat bantu terapi acrophobia dengan 
biaya yang lebih murah dan dengan kualitas yang sama dengan Virtual Reality berbasis PC. Maka dari itu, penderita phobia dapat melakukan terapi secara efektif dan dengan biaya yang lebih murah.[3]

\section{STUDY LITERATUR}

\subsection{Pengertian Fobia}

Fobia adalah rasa ketakutan yang berlebihan pada sesuatu hal. Fobia dapat mengganggu kehidupan orang yang mengidapnya. Bagi sebagian orang, perasaan takut yang dialami oleh para penderita fobia sulit untuk dimengerti.[4]

Menurut Fathiah $(2010,2)$ fobia adalah ketakutan yang tidak terkendali, irasional, dan terus-menerus dari obek tertentu, situasi, atau kegiatan. Dapat disimpulkan fobia adalah rasa takut yang tidak rasional atas sesuatu yang spesifik. Dalam kasus fobia, rasa takut dipicu oleh stimulus yang tidak benar-benar menakutkan atau mengancam keselamatan diri. Sedangkan jika stimulus tersebut memang benar-benar berbahaya atau mengancam, ini tidak termasuk fobia lagi, melainkan rasa takut yang wajar. [5]

\subsection{Perilaku Fobia}

Fobia yang dialami oleh penderita merupakan peristiwa yang disadari oleh seseorang dalam keterbatasan. Yaitu ketidakmampuan diri untuk mengatasi ketakutan. Menurut Fathiah $(2010,2)$ bahwa setiap orang pada dasarnya memiliki pengalaman sadar, dimana ia dapat berpikir mengenai dirinya dan memutuskan suatu tindakan. Tindakan yang dilakukan ketika seseorang mengalami fobia mengalami proses dalam pikiran antara lain: Pertama, tindakan yang dilakukan sebagai reaksi terhadap ancaman bersifat spontan. Kedua, tindakan itu memiliki dorongan yang sangat kuat yakni keberadaan ancaman. Ketiga, tindakan yang menjadi reaksi ini hanya memusatkan pada takut atau cemas. Semua urutan tersebut menunjukan kondisi mental seseorang yang berpengaruh terhadap fobia. Dan pengalaman fobia tersebut akan membentuk penentuan tindakan seseorang. [4]

\subsection{Penyebab Fobia}

Penyebab fobia dapat diperoleh dari suatu pengalaman langsung yang mengakibatkan traumatis. Dimana keadaan bahaya atau sekitarnya akan menghasilkan respon yang berlebihan. Menurut Fathiah (2010) ketakutan dan kecemasan manusia menjadi sumber utama yang mendorong kemunculan fobia dengan cenderungan teror dan perasaan terancam akan dikaji lewat tinjauan filosofis. Penekanan penjelasan akan dilakukan pada pengalaman dan kesaran subjektif. Reaksi yang timbul dari dorongan kecemasan dan ketakutan kemudian memicu perilaku yang tidak wajar menjadi begitu penting sebagai bentuk ekspresi takut dan ikut menentukan seberapa fatal akibat dari dorongan fobia yang dialami. [5]

Menurut Fathiah $(2010,2)$ terdapat tiga bentuk kerentanan yang memberikan kontribusi pada penyebab berbagai gangguan kecemasan fobia [5]:

Kerentanan biologis menyeluruh (generalized biological vulnerability). Kecenderungan untuk gelisah atau tegang itu tampaknya diturunkan atau diwariskan. Tetapi, kerentanan biologis menyeluruh untuk mengalami kecemasan bukanlah kecemasan itu sendiri.

Kerentanan psikologis menyeluruh (generalized psychological vulnerability). Artinya, berdasarkan pengalaman awal, mungkin tumbuh dewasa dengan disertai keyakinan bahwa dunia ini berbahaya dan diluar kontrol, dan tidak mampu mengatasi bila ada hal buruk yang menimpa.

Kerentanan psikologis spesifik (specific psychology vulnerability). Dimana manusia belajar dari pengalaman awal, misalnya dari apa yang diajarkan oleh orang tua, bahwa situasi atau objek tertentu berbahaya (meskipun sebenarnya tidak).[4]

\subsection{Pengertian Virtual Reality}

Virtual reality adalah sebuah teknologi yang memungkinkan seseorang melakukan suatu simulasi terhadap suatu objek nyata denga menggunakan komputer yang mampu membangkitkan suasana 3 dimensi, sehingga pengguna seolah-olah terlibat secara fisik.[1]

Secara sederhana, VR (Virtual reality) adalah pemunculan gambar tiga dimensi yang terlihat nyata dengan bantuan sejumlah alat tertentu. Dengan teknologi ini pengguna dapat 
merasakan dunia nyata, padahal berada pada dunia maya. Peralatan yang biasanya digunakan VR adalah helm, walker, headset, dan glove. ( Yayan, 2012) [6].

Sistem seperti ini biasanya dapat digunakan untuk perancang obat, arsitek, insinyur, pekerja medis, dan bahkan orang awam untuk melakukan aktivitas-aktivitas yang meniru dunia nyata. Lingkungan virtual reality pada umumnya menyajikan pengalaman visual, yang ditampilkan pada sebuah layar komputer atau melalui sebuah penampil stereokopik, tapi beberapa simulasi mengikutsertakan tambahan informasi hasil pengindraan, seperti suara melalui speaker atau handphone.[1]

\section{METODE PENELITIAN}

Metode yang digunakan dalam pengembangan sistem ini adalah Multimedia Development Life Cycle (MDLC) yang bersumber dari Luther dan telah dimodifikasi oleh Sutopo. Metodologi pengembangan multimedia tersebut terdiri dari enam tahap, yaitu konsep (concept), desain (design), pengumpulan materi (assembly), pengujian (testing), dan distribusi (distribution). Tahap-tahap ini tidak harus dilakukan secara berurutan, dapat bertukar posisi dengan yang lainnya. Tetapi, pada tahap konsep harus menjadi hal yang paling pertama kali untuk dikerjakan.[3]

Tahap pertama, yaitu pembuatan konsep. Aplikasi ini memiliki konsep yaitu beberapa konsep skenario yang digunakan untuk simulasi berbentuk cutscene dan penderita atau pasien harus bisa melewati skenario-skenario tersebut. Skenario itu adalah skenario menaiki elevator, menaiki kincir ria, menaiki cable car, dan skenario menaiki tangga.

Tahap kedua, yaitu desain meliputi desain sistem, struktur navigasi dan perancangan storyboard. Diterapkannya aplikasi yang simpel supaya pengguna mudah dalam menggunakannya. Pada tahap ini juga dirumuskan spesifikasi kebutuhan untuk pembuatan aplikasi seperti perangkat keras dan perangkat lunak. Perangkat keras yang digunakan adalah laptop Asus N56V yang memiliki RAM 4GB, monitor LCD 15 inchi, harddisk berukuran 750GB dan kartu grafis Intel GMA 4000 + Nvidia GT630 serta smartphone dan cardboard untuk menguji aplikasi. Perangkat yang digunakan adalah Unity 5.4.1, Autodesk Maya 2016, dan Visual Paradigm versi 12.1. untuk spesifikasi pengguna aplikasi adalah smartphone berbasis Android dengan minimal kebutuhan sistem resolusi 1920 x 1080 pada layar smartphone, versi minimal Android 5.1 'Lollipop' dan memiliki sensor Gyroscope.

Tahap ketiga adalah pengumpulan materi. Materi terapi Acrophobia berupa cara menyajikan simulasi didapat dari buku dan seorang psikiater. Musik latar belakang didapat dari internet yang disediakan Youtube, pengumpulan gambar, model tiga dimensi dan perangkat lainnya yang mendukung dalam pembuatan aplikasi dan didapat dari internet. Materi tiga dimensi dibuat dengan aplikasi Autodesk Maya. Maya adalah software untuk keperluan 3D modeling, animasi efek, serta resolusi render yang telah digunakan dalam segala hal, mulai dari desain produk dan perfilman. Maya juga memiliki beberapa fitur lain untuk mengatur tampila antarmuka terhadap pengguna.

Tahap keempat yaitu pembuatan. Aplikasi ini menggunakan aplikasi Unity. Elemen-elemen yang sudah ada akan dikumpulkan dan dirangkai sesuai dengan desain perancangan sistem yang sudah dibuat.

Tahap kelima yaitu pengujian. Pengujian aplikasi ini menggunakan metode black box yaitu dilakukan untuk menunjukan fungsi program yang sudah dibuat tentang cara operasi dan kegunaannya.

Tahap keenam yaitu distribusi. Aplikasi yang telah sesuai dibuat akan didistribusi kepada psikiater yang menangani terapi Acrophobia untuk diteliti lebih lanjut dalam bidang medis.

Perancangan sistem harus diperhatikan sasaran pengguna aplikasi yang dibuat, supaya kinerja sistem yang dibangun dapat dengan mudah digunakan bagi orang awam yang kurang mengetahui mengenai Virtual Reality. Untuk itu, dalam perancangan sistem ini dibuat use case diagram untuk alur kerja aplikasi.[3] 


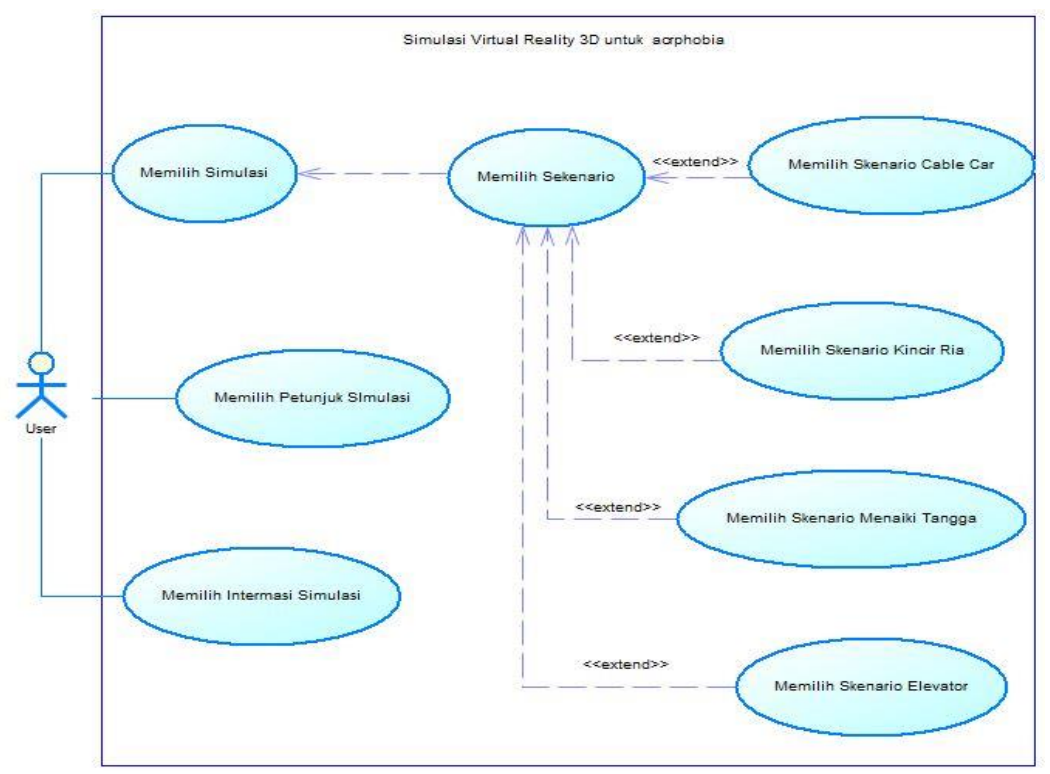

Gambar 1. Use case diagram simulasi

Penjelasan simulasi diatas yaitu untuk menjelaskan alur sistem yang terstruktur dari simulasi yang dirancang. Ketika aplikasi dibuka maka struktur navigasi dimulai dengan menampilkan tampilan halaman utama. Struktur navigasi ini ditunjukkan pada gambar dibawah ini [3]:

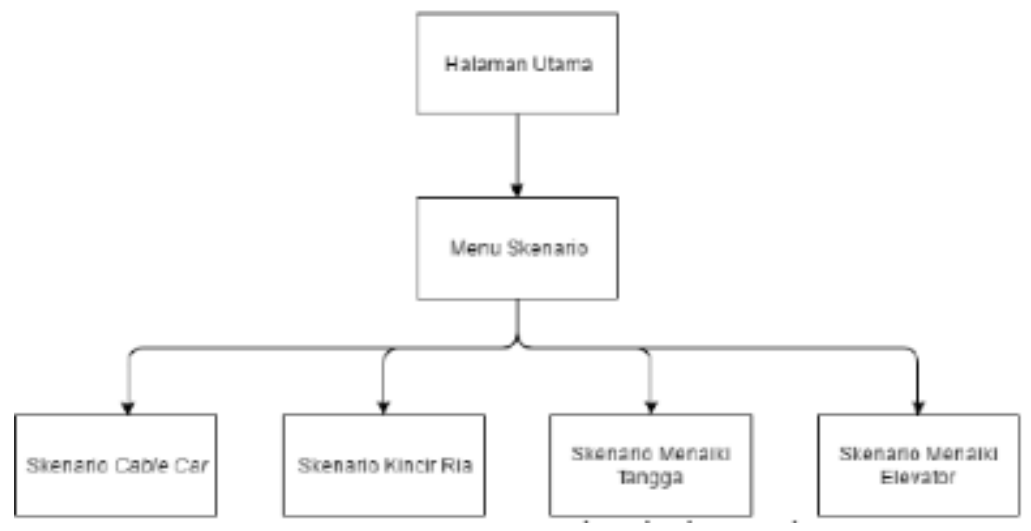

Gambar 2. Struktur Navigasi Simulasi

Pada tahap selanjutnya yaitu pembuatan perancangan tampilan dari aplikasi yang akan dibangun dan menggunakan storyboard yaitu berupa tampilan GameObject yang akan digunakan pada setiap halaman. Penjelasan dari penggunaan storyboard dijelaskan dibawah ini [3]:

- Storyboard halaman utama : Halaman awal yang ditampilkan saat pertama kali aplikasi dijalankan.

- Storyboard halaman pemilihan skenario : Ditampilkan saat tombol menu play di halaman utama ditekan. Halaman ini menampilkan pemilihan skenario dan dapat dipilih oleh pengguna.

- Storyboard halaman skenario cable car : Tempat pengguna berada pada kegiatan menaiki cable car.

- Storyboard halaman skenario kincir ria : Tempat pengguna berada pada kegiatan menaiki kincir ria.

- Storyboard halaman skenario menaiki tangga : Tempat pengguna berada pada kegiatan menaiki tangga.

- Storyboard halaman skenario naik elevator : Tempat pengguna berada pada kegiatan menaiki elevator.

Storyboard memiliki hubungan dengan storyboard yang lainnya. Berikut ini merupakan skema dari hubungan seluruh storyboard. 


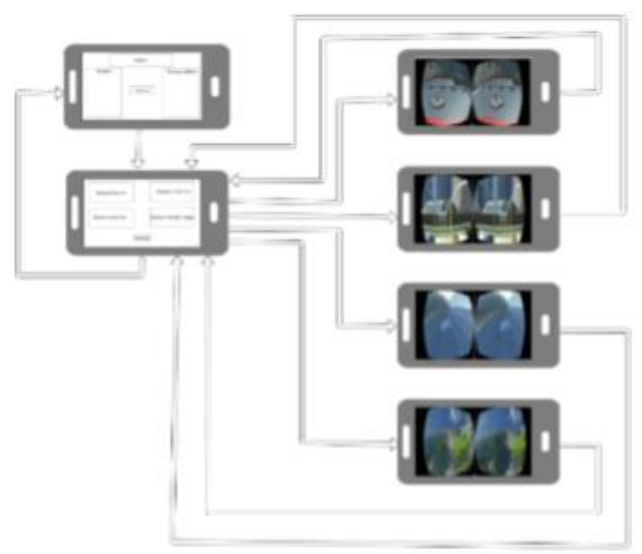

\section{HASIL DAN PEMBAHASAN}

Gambar 3. Skema hubungan antar Storyboard

\section{a. Hasil Tampilan}

1) Halaman ini merupakan halaman utama dan dijelaskan tata cara pemakaian aplikasi yang telah dirancang. Halaman utama akan ditunjukan pada gambar 4.

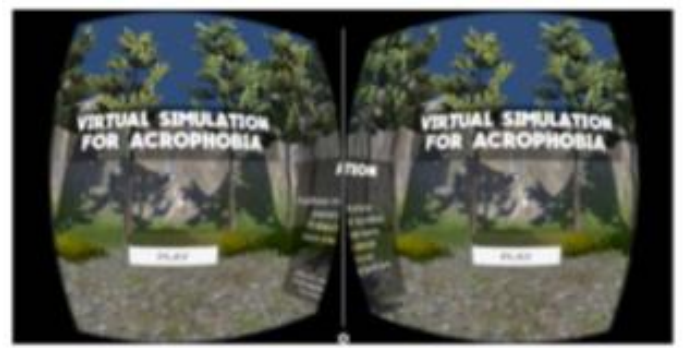

Gambar 4. Tampilan halaman utama aplikasi

2) Halaman skenario ditampilkan ketika tombol play ditekan. Pemilihan halaman skenario akan ditunjukkan oleh gambar 5 .

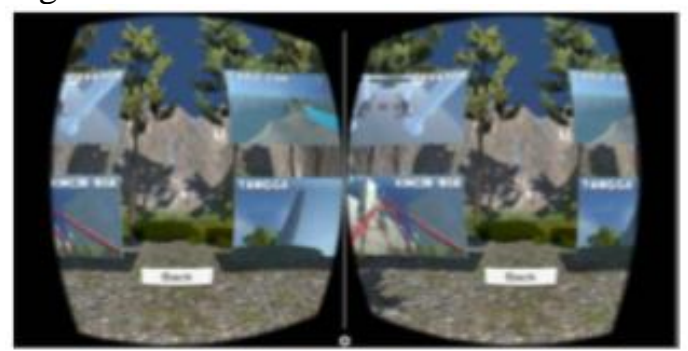

Gambar 5. Tampilan halaman pemilihan skenario

3) Halaman skenario kincir ria akan ditampilkan ketika tombol skenario kincir ria telah dipilih. Berikut merupakan tampilan halaman skenario kincir ria pada gambar 6.

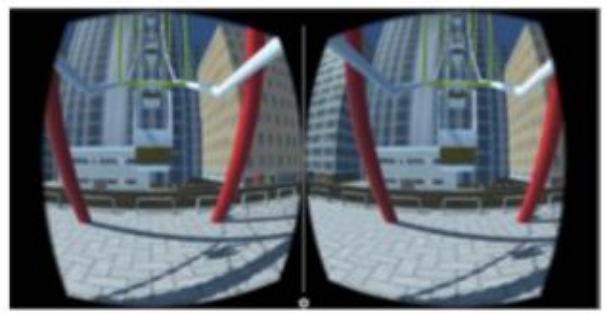

Gambar 6. Tampilan skenario kincir ria

4) Halaman skenario elevator ditampilkan ketika halaman ini dipilih 


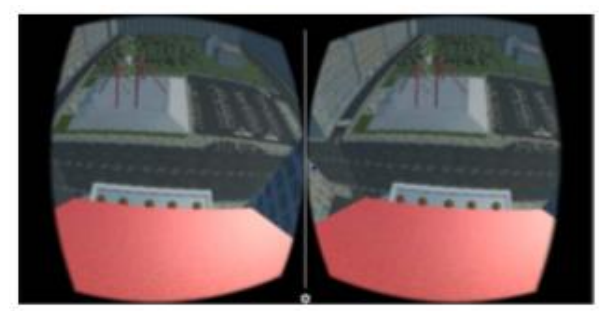

Gambar 7. Tampilan skenario elevator

5) Halaman skenario cable car ditampilkan ketika halaman ini dipilih

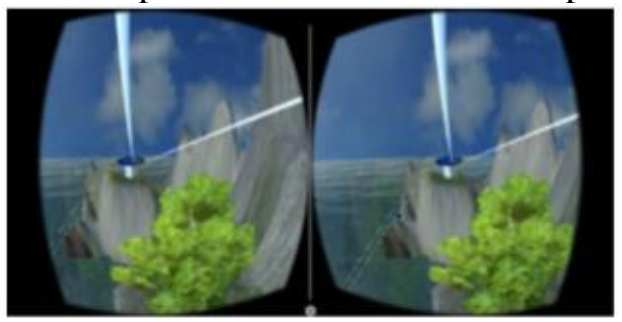

Gambar 8. Tampilan skenario cable car

6) Halaman skenario menaiki tangga ditampilkan ketika halaman ini dipilih

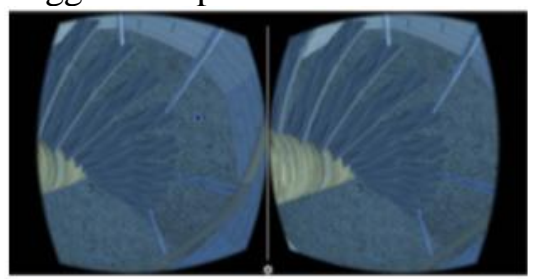

Gambar 9. Tampilan skenario Tangga

\section{b. Pembahasan Hasil Penelitian}

Pembahasa aplikasi meliputi pengecekan dan pengawasan agar performa aplikasi dapat berjalan dengan optimal pada smartphone.

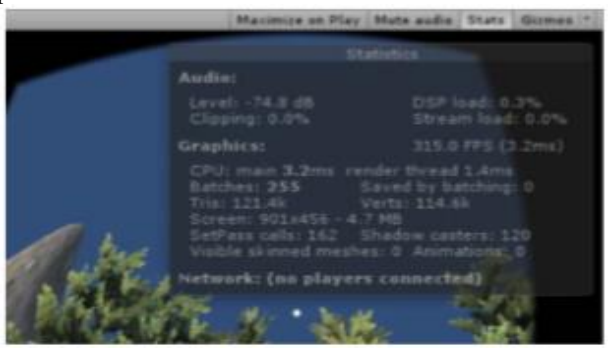

Gambar 10. Tampilan Stat pada jendela game

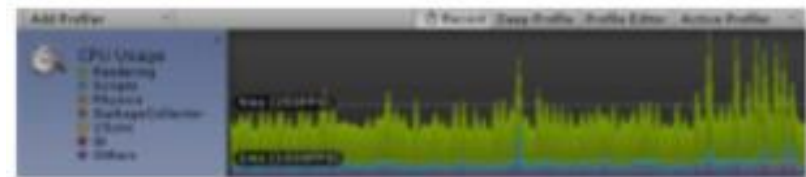

Gambar 11. Tampilan jendela Profiler

Teknik pertama yang digunakan adalah static batching. Static batching yaitu mengelompokan objek-objek yang bertautan menjadi satu kesatuan yang besar.

Static batching membutuhkan memory tambahan untuk meletakan bidang yang telah digabungkan. Jika objek-objek yang ada membagi bidang yang sama sebelum static batching, maka bidang yang lain akan dibuat tiap objek. Gambar 12 sampai gambar 15 menunjukan perubahan statistik elemen dan performa kecepatan rendering dari $19.18 \mathrm{~ms}$ menjadi $14.72 \mathrm{~ms}$. [3] 


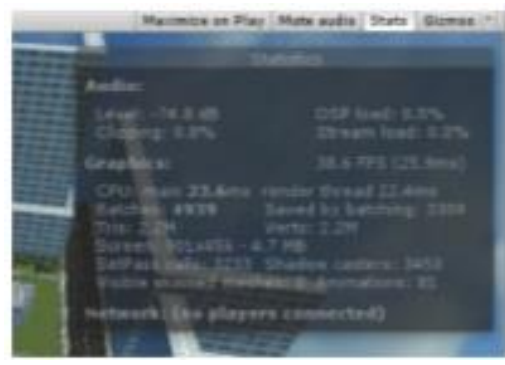

Gambar 12. Tampilan stats sebelum melakukan static batchig

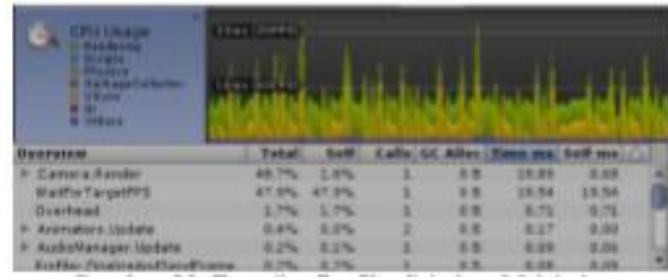

Gambar 13. Tampilan Profiler sebelum melakukan Static Batching

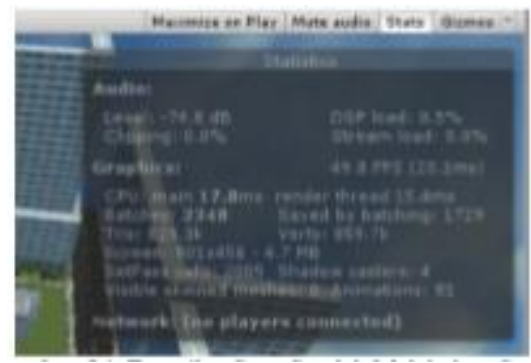

Gambar 14. Tampilan static setelah melakukan static batching

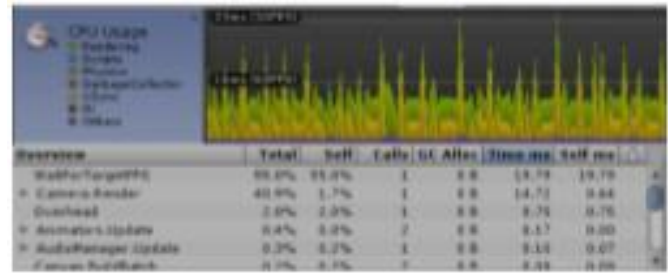

Gambar 15. Tampilan Profiler setelah melakukan static batching

Teknik kedua yaitu occlusion culling, yaitu fitur yang menonaktifkan proses rendering pada objek yang tidak dilihat oleh kamera karena objek lain. Fitur ini tidak terjadi secara otomatis dalam pemrosesan 3D karena objek yang jauh dari kamera sering digambar pertama kali dan objek yang lebih dekat digambar setelahnya.

Proses Occlusion Culling akan melihat skenario menggunakan kamera virtual untuk membangun hirarki potensial objek yang terlihat. Berbekal informasi tersebut, Unity akan memastikan hanya objek yang terlihat yang akan dilakukan proses rendering. Hal ini membuat pemanggilan gambar berkurang dan meningkatkan performa. [3]

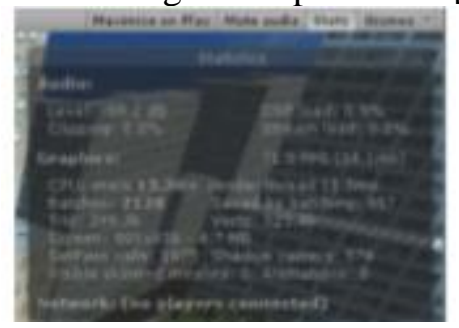

Gambar 16. Tampilan stats sebelum melakukan Occlusion Culling 


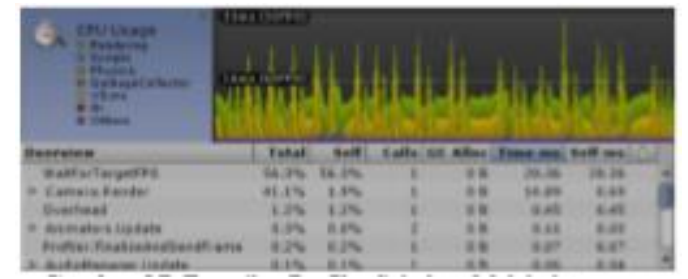

Gambar 17. Tampilan profiler sebelum melakukan Occlusion Culling

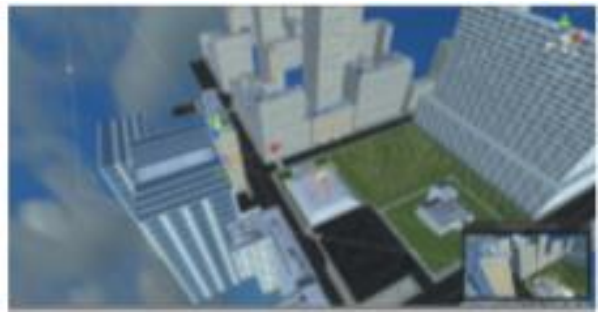

Gambar 18. Tampilan lingkungan sebelum melakukan Occlusion Culling

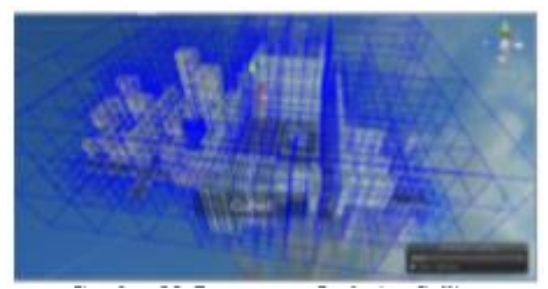

Gambar 19. Pemorosesan Occlusion Culling

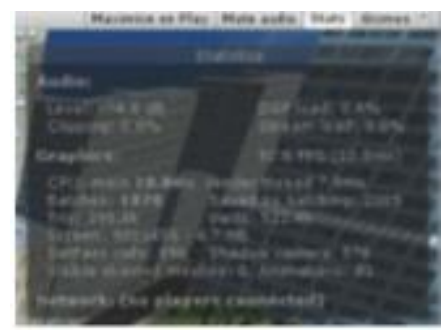

Gambar 20. Tampilan Stats setelah melakukan occlusion culling

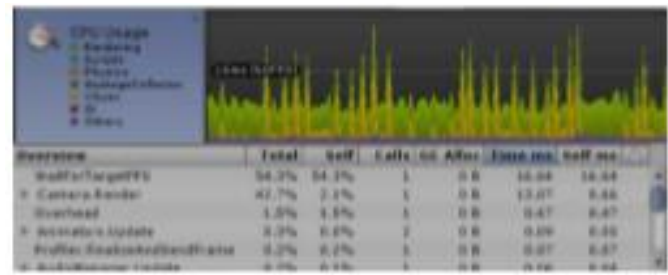

Gambar 21. Tampilan profiler setelah melakukan acclusion culling

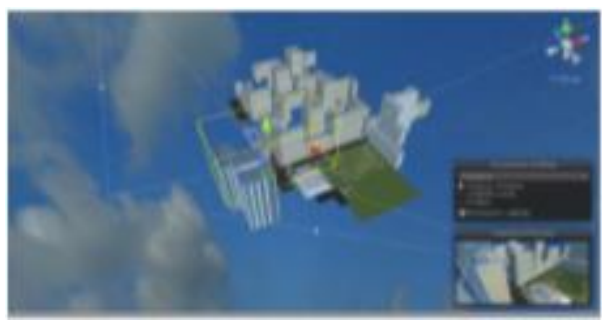

Gambar 22. Tampilan Lingkungan setelah melakukan Occlusion Culling

Teknik ketiga yaitu level of detail atau LOD. LOD adalah salah satu cara untuk mengatur kualitas objek tergantung seberapa jauh kamera dengan objek tersebut dengan cara mengubah- 
ubah objek dengan objek dengan kualitas detail yang bagus sampai dengan kualitas detai yang buruk, serta dapat uga meguragi komponen-komponen yang ada pada objek.

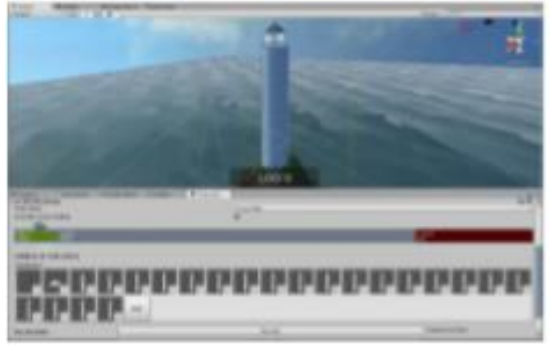

Gambar 23. Modal yang ditampilkan pada sebuah objek pada LOD 0 (Jarak Kamera Dekat )

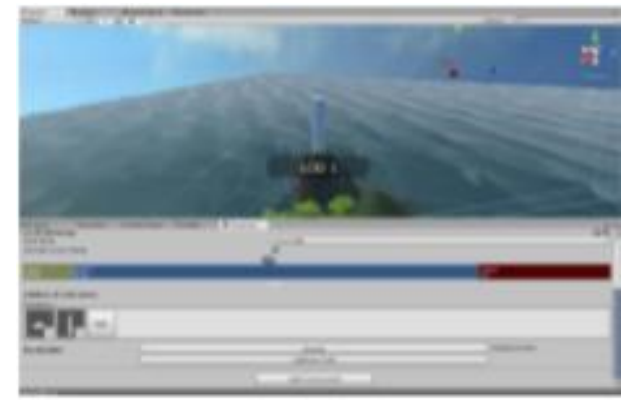

Gambar 24. Model yang ditampilkan pada sebuah objek pada LOD 1 ( Jarak Kamera Jauh )

\section{KESIMPULAN}

Berdasarkan hasil pegujian pada aplikasi simulasi 3D Virtual Reality dengan mengoptimalkan teknik rendering elemen-elemen pada aplikasi, maka performa simulasi dapat berjalan dengan baik pada smartphone yang memiliki resolusi 1920 x 1080. Aplikasi dapat di ekspor dan di instalasi dengan baik. Meskipun pemakaian smartphone dengan cardbard masih membuat mata pegguna kelelahan, tetapi semua elemen yang ada pada aplikasi simulasi sudah dapat berjalan.

Berdasarkan kesimpula diatas, dapat diketahui bahwa aplikasi ini masih dapat dikembagkan lebih jauh. Peneliti selanjutnya dapat menambah fitur skenario untuk mendiagnosis seberapa parah phobia yang penguna derita. Selain itu dapat juga ditambahkan simulasi yang interaktif supaya pengguna tidak jenuh dan juga diperlukan penilitian lebih lanjut untuk mengetahui dampak klinis dari aplikasi terhadap pengguna. Pegembang juga dapat menganalisis efek dari penggunaan aplikasi terhadap penderita secara langsung dan meneliti lebih dalam pada bidang medisnya.

\section{DAFTAR PUSTAKA}

[1] P. Media, T. Menggunakan, R. Dengan, M. Desentisiasi, U. Penderita, and F. T. Hewan, "Oleh : NUR SHABRINA," 2017.

[2] D. Untuk and M. Tugas, "MAKALAH SISTEM VIRTUAL REALITY," 2015.

[3] G. A. Putra, R. Kridalukmana, and K. T. Martono, "Pembuatan Simulasi 3D Virtual Reality Berbasis Android Sebagai Alat Bantu Terapi Acrophobia," J. Teknol. dan Sist. Komput., vol. 5, no. 1, p. 29, 2017.

[4] U. K. Indonesia and Budiyanto, "PEMANFAATAN AUGMENTED REALITY SEBAGAI MEDIA TERAPI PENDERITA FOBIA TERHADAP HEWAN ( STUDI KASUS : RUMAH SAKIT PUSAT AU DR . M . SALAMUN BANDUNG ) Budiyanto Teknik Informatika Universitas Komputer Indonesia," pp. 1-8, 2015.

[5] Chaerany, Fathiah. "Analisis Phobia sebagai pemahaman kesadaran manusia dalam pemusatan perhatian pada pengalaman subjektif, “. Depok : FIB UI DEPOK, 2010.

[6] Yayan. 2012. Apa itu Virtual reality ? . http://untitled-pages.blogspot.co.id/2012/ 06/ apa-ituvirtual-reality.html. (Diakses 9 Februari 2017). 